\title{
Problems and Prospects of Urban Environmental Management in Pakistan
}

\author{
MUHAMMAD ASLAM KHAN
}

\begin{abstract}
Discussions on environmental conditions often assume that urbanisation contributes to the degradation of the environment. However, urbanisation per se is not detrimental to the environment. Concentrations of population and economic activities through urbanisation offer opportunities in providing environmental infrastructure and health services costeffectively, because of economies of scale. It also provides opportunities to effectively internalise environmental costs; because concentration of economic activities reduces user charges and costs of tax collection, enforcement, and wastes management, which are essential to environmental protection. Nevertheless, while providing opportunities the process of urbanisation also generates environmental pressures. A nation that is unable to utilise the opportunities and alleviate the pressures through integrated environmental, economic and physical planning finds that mismanaged urbanisation can pose enormous environmental and economic problems that become increasingly difficult to solve with time. Unfortunately, Pakistan is one of the countries which have not managed the process of urbanisation effectively.

This paper, after tracing the urbanisation trends in Pakistan, discusses the existing and emerging environmental impacts and risks. The country is at the stage of risk transition where modern risks caused by industrial and traffic pollution, such as chemicals, heavy metals and noise, combine with the traditional risks such as bacteriological and parasitic infections caused by inadequate infrastructure facilities particularly water supply and sanitation. The paper also analyses the responses to urban environmental problems in terms of approaches to sustainable urban development. Finally, it outlines the holistic policy directions to environmentally sound and sustainable urban development, including institutional, regulatory, economic and participatory measures.
\end{abstract}

\section{URBAN GROWTH AND ECONOMY}

The 1993 population of Pakistan was estimated to be around 122.7 million, and is projected to be around 148.6 million by the year 2000. Urban population, as a percentage of total population, increased from 28.3 percent in 1981 to 30.5 percent in 1993 [Government of Pakistan (1996)]. By the year 2020, the proportion of urban population is expected to be over 50 percent of the total population. The number of urban settlements of more than 10,000 persons also increased from 374 in 1981 to 496 in 1991 and is expected to increase further in the future [Government of Pakistan (1996)]. The rapid increase in population has exerted great pressures on already

Muhammad Aslam Khan is Environmental Affairs Officer, Economic and Social Commission for Asia and the Pacific, Bangkok. 
overstretched resources of cities, added to the housing, infrastructure, services and utilities backlog, and affected the environmental quality as well as functioning of the cities as economic hubs.

Although urban settlements occupy only about 1 percent of Pakistan's land area, they contribute almost 48 percent to the Gross National Product (GNP), over 80 percent to manufacturing, 58 percent to trade and 52 percent to services sector [ADB (1993)]. In 1991-92, the share of manufacturing sector in the urban economy was 32 percent and that of services was 47 percent [ADB (1993)]. The dynamism of the cities is also evident from the annual growth rate of urban product, which has been 6.8 percent per annum compared to rural product of 4.2 percent.

As centres of economic and demographic growth the urban centres also consume large amount of natural resources and generate wastes which if not managed properly has serious impact on the environment. Industrial effluent and wastes, heaps of domestic and commercial garbage choked and overflowing sewers and traffic pollution in cities of Pakistan are typical examples of environmental degradation that threatens the sustainability of urban areas.

\section{ENVIRONMENTAL PROBLEMS}

The cities of Pakistan are currently passing through the stage of risk transition in which modern stresses such as chemicals, heavy metals and noise combine with the traditional ones such as bacteria and disease vectors. Figure 1 shows a wide spectrum of environmental problems from unsatisfactory water supply and sanitation due to lack of basic infrastructure to release of man-made chemicals and hazardous wastes from the industrial and technological processes into water, air and soil. The resultant health risks have also been listed.

\section{(a) Water Pollution}

Water pollution in urban Pakistan results from the uncontrolled release of domestic, agriculture and industrial effluents. There are three main sources of pollution: bacterial and organic liquids and solids from domestic sewage; toxic metals, organic loads, acids, and other less-toxic but still polluting substances from industrial discharges; and chemical pollution in the form of pesticide and fertiliser run-off from agricultural lands. All three cause the contamination of both surface and ground-water supplies and both directly and through food chain can cause serious damage to human health (Figure 2).

Solid and liquid excreta generated in urban settlements along with kitchen and wash waste water are the major sources of water pollution and the cause of widespread water-borne diseases. The seriousness of the situation is clear from the fact that diseases of a gastro-intestinal nature account for 25.30 percent of the cases 
Fig. 1. Risk Transition in Pakistan.

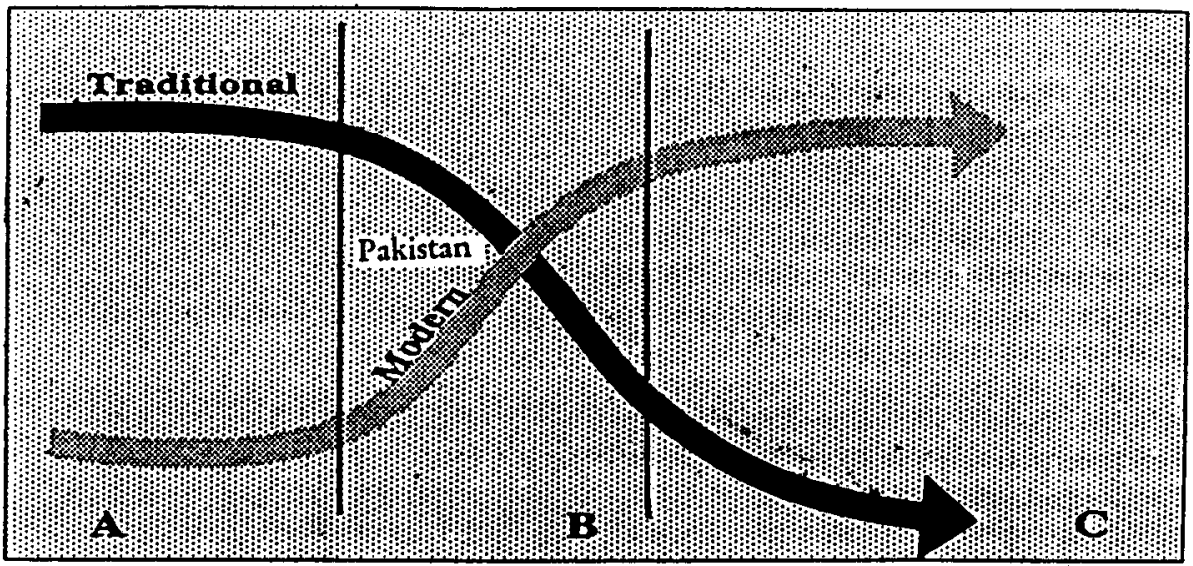

Stage of Development

\section{Traditional Risks}

Malnutrition

\section{Contaminated water}

Environmental disease vectors

Lack of sanitation

Cooking fire air pollution

Substandard shelter

Associated Diseases
Diarrhoea
Acute respiratory infection
Malaria
Tuberculosis
Hepatitis
Typhoid
Intestinal Helminths etc.

\section{Modern Risks}

Automobile and industrial air pollution

Surface and ground water pollution

Radioactivity

Indoor air pollution

Toxic chemical releases

Hazardous waste

Urban stress

Noise

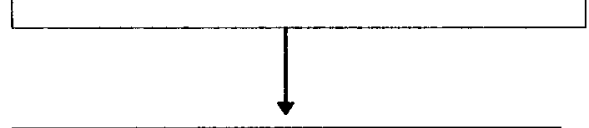

Associated Diseases

Cancer

Cardio-vascular

Chemical poisoning

Heavy metal poisoning

Stress related diseases 
Fig. 2. Water Pollution and Chain of Pathways that Lead to

Human Exposure to Water Borne Pollutants.

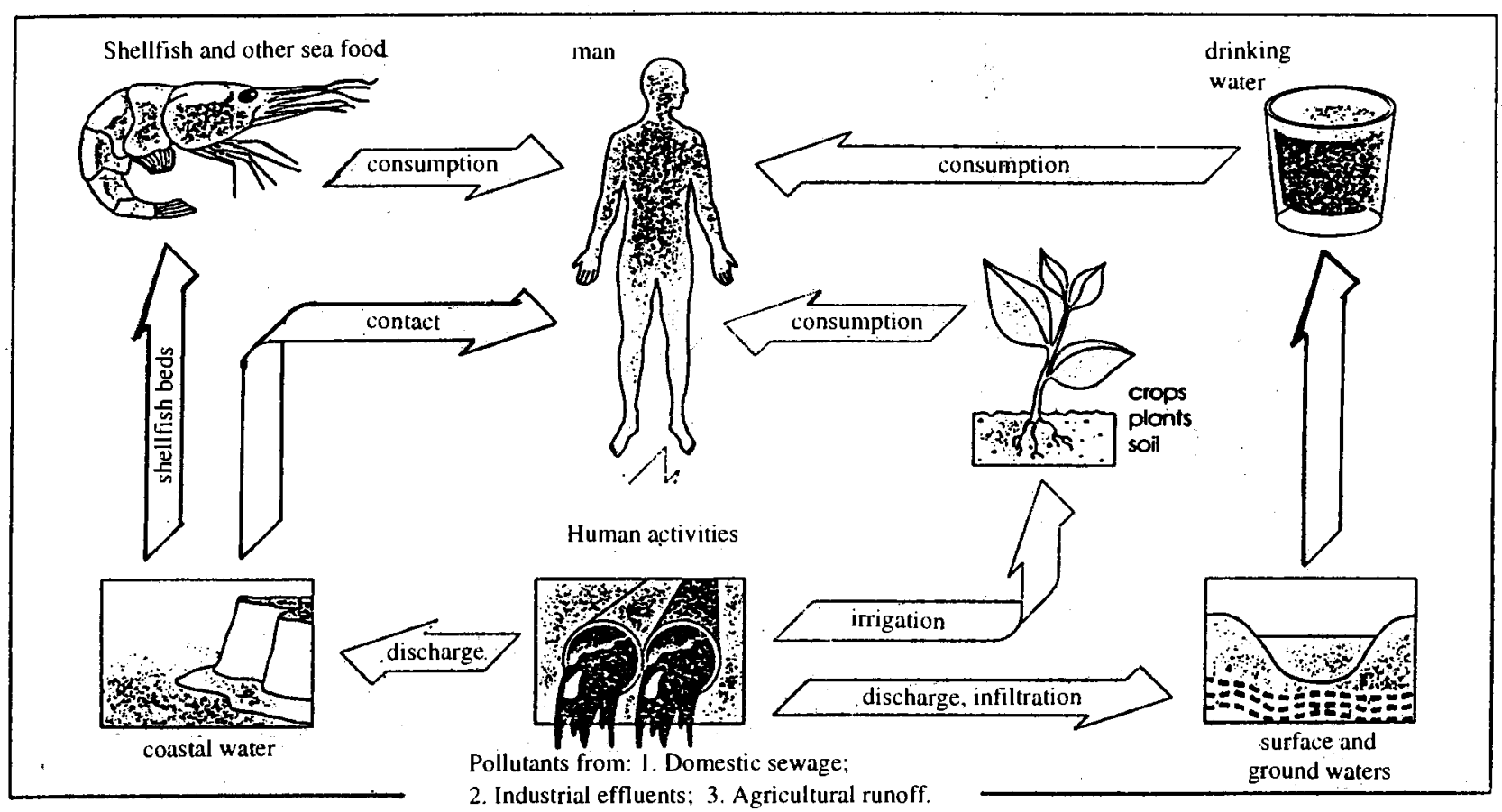


seen at public hospitals and dispensaries in Pakistan [Government of Pakistan (1992)]. Further, approximately 60 percent of infant deaths are due to infectious and parasitic diseases, most of them water-borne caused primarily by human excrement. Karachi alone discharges approximately 300 million gallons per day of sewage; Lahore, approximately 240 million gallons. The excreta from urban areas is around 8,000 tonnes per day. An estimated 4,160 tonnes of the urban excreta (52 percent) is disposed of into sewers, with the remainder being deposited on the roadside, into water-ways, or incorporated in solid waste [Government of Pakistan (1992)]. Major cities dispose of their largely untreated sewage into irrigation systems, where the waste water is reused, and/or into streams, and other water bodies without any consideration for their assimilative capacity.

The industries creating environmental hazards are primarily the manufactures of chemicals (including pesticides), textiles, pharmaceuticals, cement, electrical and electronic equipment, glass and ceramics, pulp and paper board; leather tanning; food processing; electro-plating; and petroleum refining. Pollutants associated with various industrial sub-sectors are shown in Table 1.

No systematic or complete survey has been done of the sources, volumes, and characteristics of industrial pollution in Pakistan, although partial surveys, investigations of particular sources, and observations have shown the seriousness of industrial pollution in a number of locations. For all practical purposes, industries do not manage their waste water effluents through process controls, waste recycling, or end-of-pipe treatment. In Kala Shah Kaku industrial area near Lahore, for example, the various chemical industries, tanneries, textile plants, steel re-rolling mills, and other operations discharge effluents containing hydrochloric acid and high levels of organic matter directly into streams and canals. Two large industrial zones in Sindh Province-SITE (Sindh Industrial Trading Estate) and LITE (Landhi Industrial Trading Estate) — discharge large quantities of organic matter, heavy metals, oils and greases, and other materials into local rivers. In Korangi in Karachi, where LITE is located, 35 tonnes of suspended solids, 376 tonnes of dissolved solids, 2 tonnes of ammonia, and 1.4 tonnes of arsenic oxide, among other chemicals, (Table 2) are discharged into the city's already polluted harbour each day. Over 235 industries in Faisalabad discharge high levels of solids, heavy metals, aromatic dyes, inorganic salts, and organic materials directly into the municipal sewers without any pretreatment [Government of Pakistan (1992)], polluting nearby lands. Tanneries in Karachi, Kasur and Sialkot are similarly pollutions water bodies and nearby lands. Contamination of shallow ground waters in urban areas from industrial wastes has also been reported.

\section{(b) Air Pollution}

The combined emissions of air pollutants from industry, power generation, transportation, domestic activities (particularly energy use), agriculture, and 
commercial institutions are growing rapidly (Table 3) and air pollution has been estimated to cost Pakistan about Rs 15 billion per year from adverse health and other effects [Government of Pakistan (1992)]. No doubt the classic source of air pollution is the factory including brick kiln smoke stacks. Such stationary, point-source emissions are highly visible and represent a significant threat to those living nearby. By volume, however, they represent less of a threat to the overall health than do mobile sources such as automobile and other vehicles. During the last few years, traffic in urban areas particularly in the metropolitan cities has increased tremendously. The total number of vehicles in the country increased from about 0.85 million in 1982, to 2.8 million in 1995, showing an overall increase of 229 percent in

Table 1

Selected Pollutants Associated with Industry

\begin{tabular}{ll}
\hline Industrial Subsector & \multicolumn{1}{c}{ Potential Pollutants* } \\
\hline Chemicals & $\begin{array}{l}\text { Sulphuric and nitric acids, ammonia, } \\
\text { fluorocarbons }\end{array}$ \\
Pesticides & $\begin{array}{l}\text { Organohalogens, organophosphates, } \\
\text { other toxic organics, arsenic }\end{array}$ \\
Textiles & $\begin{array}{l}\text { Hydrochloric, sulphuric acids, high } \\
\text { BOD (organic content), dye various } \\
\text { organic chemicals and detergents }\end{array}$ \\
Pharmaceuticals & Ammonia, acids, zinc \\
Leather Tanning & $\begin{array}{l}\text { Heavy metals (chromium, cadmium, } \\
\text { etc.), various organic chemicals, }\end{array}$ \\
acids, high BOD & Ammonia, sulphur dioxide \\
Food Processing & Alkalines, limestone dust \\
Cement & Fluorocarbons, heavy metals \\
Electrical/Electronics & (including \\
selenium) & Arsenic, fluorine \\
Glass/Ceramics & Phenols, sulphides, oily residues, \\
ammonia & Mercaptans (organic sulphides) high \\
&
\end{tabular}

Source: Government of Pakistan (1992).

*Quantities and characteristics dependent on type of manufacturing process and whether waste treatment exists. 
Table 2

Toxic Substance Concentrations in Effluents of Sample Industries, Karachi

(Milligrams per Litre)

\begin{tabular}{lccccc}
\hline $\begin{array}{l}\text { Type Of } \\
\text { Industry }\end{array}$ & Copper & Cadmium & Zinc & Nickel & Lead \\
\hline $\begin{array}{l}\text { Suggested } \\
\quad \text { Standard* }\end{array}$ & 1.00 & 0.10 & 5.00 & 1.00 & 0.50 \\
$\quad$ Food & & & & & \\
$\quad$ Processing & 0.43 & 0.03 & 0.24 & 0.27 & 0.23 \\
Oil Mill & 0.03 & 0.03 & 2.19 & 0.65 & 0.48 \\
Beverage & 0.09 & 0.04 & 2.06 & 0.41 & 0.04 \\
Textile & 0.02 & 0.05 & 5.30 & 0.51 & - \\
Tannery & 0.30 & 0.15 & 7.00 & 1.14 & 1.80 \\
Chemical & & & & & \\
$\quad$ Alkali & 0.14 & 0.03 & 0.22 & 1.18 & 0.66 \\
Paint & & & & & \\
$\quad$ Manufacture & 0.07 & 0.94 & 0.48 & 0.20 & 3.88 \\
Shipyard & 0.28 & 0.10 & 1342.50 & 0.74 & 11.75 \\
Cement & 0.33 & 0.33 & 2.66 & 1.00 & 0.79 \\
\hline
\end{tabular}

Source: Based on the EEC report to the Environment and Urban Affairs Division, Government of Pakistan.

Table 3

Estimated Air Pollutants from Various Economic Sectors

\begin{tabular}{|c|c|c|c|c|c|c|c|c|c|}
\hline \multirow[t]{2}{*}{ Sector } & \multicolumn{3}{|c|}{$1977-78$} & \multicolumn{3}{|c|}{ 1987-88 } & \multicolumn{3}{|c|}{ 1997-98 } \\
\hline & $\mathrm{CO}_{2}$ & $\mathrm{SO}_{2}$ & $\mathrm{NO}_{\mathrm{x}}$ & $\mathrm{CO}_{2}$ & $\mathrm{SO}_{2}$ & $\mathrm{NO}_{\mathrm{x}}$ & $\mathrm{CO}_{2}$ & $\mathrm{SO}_{2}$ & $\mathrm{NO}_{x}$ \\
\hline Industry & 12,308 & 19 & $\mathrm{n} / \mathrm{a}$ & 26,680 & 423 & $\mathrm{n} / \mathrm{a}$ & 53,429 & 982 & $\mathrm{n} / \mathrm{a}$ \\
\hline Transport & 7,068 & 52 & $\mathrm{n} / \mathrm{a}$ & 10,254 & 57 & $\mathrm{n} / \mathrm{a}$ & 18,987 & 105 & $\mathrm{n} / \mathrm{a}$ \\
\hline Power & 3,640 & 4 & 3 & 11,216 & 95 & $\mathrm{n} / \mathrm{a}$ & 53,062 & 996 & 76 \\
\hline Domestic & 16,601 & 5 & $\mathrm{n} / \mathrm{a}$ & 24,054 & 16 & $\mathrm{n} / \mathrm{a}$ & 39,98 & 040 & $\mathrm{n} / \mathrm{a}$ \\
\hline Agriculture & 845 & 5 & $\mathrm{n} / \mathrm{a}$ & 4,490 & 28 & $\mathrm{n} / \mathrm{a}$ & 6,368 & 40 & $\mathrm{n} / \mathrm{a}$ \\
\hline Commercial & 1,726 & 11 & $\mathrm{n} / \mathrm{a}$ & 2,587 & 13 & $\mathrm{n} / \mathrm{a}$ & 4,261 & 25 & $\mathrm{n} / \mathrm{a}$ \\
\hline
\end{tabular}

Source: Government of Pakistan (1992).

n.a. $=$ not applicable 
13 years. It is estimated that with the present rate of growth, the number of vehicles would increase to 4.5 million by the year 2000 [Government of Pakistan (1996a)].

As Table 4 indicates, the truly dangerous pollutants to human health-those that can cause bronchial irritation, hasten asthma attacks, and irritate the eyes-arise primarily from automobiles. Motor vehicle emissions alone in Lahore account for approximately 90 percent of the total annual emissions of hydrocarbons, aldehydes, and carbon monoxide, and for smaller but still the largest proportion of the emissions of sulphur dioxide and nitrogen oxides. The situation is aggravated by lack of vehicle maintenance. It has been estimated that an average Pakistani vehicle emits 20 times

Table 4

Lists Recommended WHO Guidelines for Maximum Exposure to the Major Air Pollutants and some Possible Health Effects

if these Recommendations are Exceeded

\begin{tabular}{|c|c|c|}
\hline Pollutant & Possible Effects & $\begin{array}{l}\text { WHO Guideline } \\
\text { Annual Mean }\end{array}$ \\
\hline Sulphur Dioxide & $\begin{array}{l}\text { Worsening respiratory illness from } \\
\text { short-term exposure, increased } \\
\text { respiratory symptoms, including chronic } \\
\text { branchitis, from long-term exposures }\end{array}$ & $40-60 \mu \mathrm{g} / \mathrm{m}^{3}$ \\
\hline $\begin{array}{l}\text { Suspended } \\
\text { Particulate } \\
\text { Matter }\end{array}$ & $\begin{array}{l}\text { As for } \mathrm{SO}_{2} \\
\text { combined exposure to } \mathrm{SO}_{2} \text { and SPM } \\
\text { are associated with pulmonary effects }\end{array}$ & $\begin{array}{l}\text { black smoke } \\
40-60 \mu \mathrm{g} / \mathrm{m}^{3} \\
\text { total SPM } \\
60-90 \mu \mathrm{g} / \mathrm{m}^{3}\end{array}$ \\
\hline \multirow[t]{2}{*}{ Lead } & $\begin{array}{l}\text { Blood enzyme changes, anaemia, } \\
\text { hyperactivity and neurobehavioural } \\
\text { effects }\end{array}$ & $0.5-1 \mu \mathrm{g} / \mathrm{m}^{3}$ \\
\hline & & $\begin{array}{l}\text { WHO Guideline } \\
\text { not to be } \\
\text { Exceeded }\end{array}$ \\
\hline $\begin{array}{l}\text { Nitrogen } \\
\text { Dioxide }\end{array}$ & $\begin{array}{l}\text { Effects on lung function in asthmatics } \\
\text { from short-term exposures }\end{array}$ & $\begin{array}{l}150 \mu \mathrm{g} / \mathrm{m}^{3} \\
\text { (for } 24 \mathrm{hr} \text { ) }\end{array}$ \\
\hline $\begin{array}{l}\text { Carbon } \\
\text { Monoxide }\end{array}$ & $\begin{array}{l}\text { Reduced oxygen-carrying capacity of } \\
\text { blood }\end{array}$ & $\begin{array}{l}10 \mathrm{mg} / \mathrm{m}^{3} * \\
\text { (for } 8 \mathrm{hr} \text { ) }\end{array}$ \\
\hline
\end{tabular}


as much hydrocarbons, 25 times as much carbon monoxide, and 3.6 times as much nitrous oxides in grams per kilometre as the average vehicle in the United States [Government of Pakistan (1992)]. As such, air pollution along busy roads and narrow streets of the main cities should have an order of magnitude much greater than would be predicted from the number of vehicles on the road.

\section{(c) Land Pollution}

The main cause of land pollution is industrial effluents (such as those of tanneries) and solid waste from both municipal and industrial sources. Pakistan generates about 19,000 tonnes of solid waste per day from urban areas. This amounts to about 7 million tonnes per year. In cities such as Lahore and Karachi, waste disposal typically accounts for 20-50 percent of municipal expenditures. Even so, only about 55 percent of these two urban areas, generally the wealthier sections, benefit from municipal collections [Government of Pakistan (1992)]. Solid domestic waste is typically dumped into low-lying land without applying even the rudimentary modern sanitary landfill methods. The result is unsightly and unsanitary conditions at and around dump sites, waste of land that could be turned to more productive purposes, and the loss of potentially valuable recyclable materials.

Of considerable concern is the likelihood that quantities of toxic industrial wastes such as discharged batteries have been dumped in municipal disposal areas or are being dumped directly onto lands adjacent to factories with no record of their location, quantity, or toxic composition. There are thousands of small electroplating and other units which are dumping heavy metals on the land and into water without realising the risks they are causing in the environment. Disposal of medical waste on land is another hazard. In Pakistan, around 250,000 tonnes of hazardous medical waste is produced annually [Government of Pakistan (1996a)]. The hazardous medical wastes can be categorised into infectious chemical and radio-active wastes. Around 10-15 percent of medical wastes is considered infectious [Government of Pakistan (1996a)], commonly associated to which are the two most common and dangerous diseases-Hepatitis B and Acquired Immune-Deficiency Syndrome (AIDS). Chemical and radio-active wastes also have high risk potential for causing cancer. Unfortunately, these wastes are also usually dumped, alongwith others, they may remain at these collection points, normally for a few days with great potential health hazards.

\section{(d) Urban Environmental Problems Viewed in Spatial Scale}

Viewed at a spatial scale urban environmental problems vary in their impact and intensity. Figure 3 shows the characteristic problems and the related infrastructure and services needed to address these on a spatial scale. The following points are notable: 
Fig. 3. Urban Environmental Problems Viewed in Spatial Scale.

\begin{tabular}{|c|c|c|c|c|}
\hline \multirow[t]{2}{*}{ SPATIAL SCAL } & & \multirow{2}{*}{ COMMUNITY } & \multirow{2}{*}{$\begin{array}{l}\text { METROPOLITAN } \\
\text { AREA }\end{array}$} & \multirow{2}{*}{$\begin{array}{l}\text { PROVINCIAL/ } \\
\text { NATIONAL }\end{array}$} \\
\hline & $\begin{array}{l}\text { HOUSEHOLD/ } \\
\text { WORKPLACE }\end{array}$ & & & \\
\hline $\begin{array}{l}\text { Key Infrastructure } \\
\text { and Services }\end{array}$ & $\begin{array}{l}\text { Shelter } \\
\text { water storage } \\
\text { onsite sanitation } \\
\text { garbage storage } \\
\text { stove } \\
\text { ventilation }\end{array}$ & $\begin{array}{l}\text { piped water } \\
\text { sewerage } \\
\text { garbage collection } \\
\text { drainage } \\
\text { streets/lanes }\end{array}$ & $\begin{array}{l}\text { industrial parks } \\
\text { roads } \\
\text { interceptors } \\
\text { treatment plants } \\
\text { outfalls } \\
\text { landfills }\end{array}$ & $\begin{array}{l}\text { highways } \\
\text { water sources } \\
\text { power plants }\end{array}$ \\
\hline $\begin{array}{l}\text { Characteristic } \\
\text { Problems }\end{array}$ & $\begin{array}{l}\text { substandard } \\
\text { housing } \\
\text { lack of potable } \\
\text { water } \\
\text { lack of sanita- } \\
\text { tion } \\
\text { disease vectors } \\
\text { indoor air } \\
\text { pollution }\end{array}$ & $\begin{array}{l}\text { excreta laden } \\
\text { water/soils } \\
\text { trash dumping } \\
\text { noise stress } \\
\text { natural and } \\
\text { man-made } \\
\text { disasters }\end{array}$ & $\begin{array}{l}\text { traffic congestion } \\
\text { accidents } \\
\text { ambient air } \\
\text { pollution } \\
\text { toxic dumps }\end{array}$ & $\begin{array}{l}\text { water pollution } \\
\text { ecological } \\
\text { areas lost }\end{array}$ \\
\hline
\end{tabular}

Source: Bartone (1991).

- health impacts are greater and more immediate at the household or community level and tend to diminish in intensity as the spatial scale increases;

- equity issues arise in relation to (a) the provision of basic services at the household or community scale and (b) intertemporal externalities at the national scale, particularly the intergenerational impacts implicit in unsustainable resource use and release of pollutants; and

- levels of responsibility and decision-making correspond to the scale of impact, but existing jurisdictional arrangements often violate this principle. [Bartone (1991)].

\section{DETERMINANTS OF URBAN ENVIRONMENTAL DEGRADATION}

\section{(a) Inappropriate Economic Policy/Incentive Systems}

Environmental degradation is a classic example of the divergence between social and private benefits and costs. A profit-seeking firm (or budget-conscious agency) will naturally take advantage of the "free" waste disposal services offered by air, water and land and will use the lowest-cost fuels, which are often the most 
polluting. It will not undertake pollution control unless the alternative seems more costly-e.g., in effluent fees, fines, public image, or possible lawsuits. This is not the case in Pakistani cities. As such the costs are borne by those who do not directly benefit from the pollution-generating activity. With water pollution, for instance, the public has health problems and the water supply agency has higher water treatment costs. Such costs are "external" (both spatially and temporally) to the firm. Where tax revenues are used to clean up pollution - in effect subsidising the polluters-the masses bear a double burden. The problem of externalities is exacerbated by the "growth-first" strategy adopted by the governments. The "growth first" approach is more expensive in the long run both economically and in human suffering, therefore adoption of a strategy of concurrent growth with environmental protection is imperative.

\section{(b) Inappropriate Pricing of Resources and Services}

Low prices for water, energy and other inputs to industry can encourage their overuse. In addition, according to Bartone (1991), inappropriate pricing of urban services results in inefficient allocation and inequitable distribution, as manifested by:

- urban poor without services despite a certain willingness and ability to pay;

- $\quad$ subsidised services for upper economic classes;

- pervasive misallocation between capital and recurrent expenditures; and

- inability to recover costs and finance services locally leading to greater dependence on fiscal transfers from Federal Government.

Since the environmental costs associated with production are external to industry, they do not appear in the price of the goods and services produced. This, according to economic logic, leads to excess demand for the product. Alternative pricing rules such as marginal user cost or marginal opportunity cost have been suggested, which would include environmental values in the prices paid by urban consumers [Leitmann (1991)].

\section{(c) Institutional Constraints}

In Pakistan the allocation of functions and powers between various public agencies are constitutionally based on the assumption that the higher level of Government (Federal and Provincial) authorities will formulate policies and strategies, while the lower level of government (provincial or local) authorities will implement these. However, there is an imbalance in actual practice when the higher 
level of government is also performing the functions of the lower level of government. Furthermore, there is overlapping in management of certain utilities in urban areas. For example, in cities with municipal corporations, water supply, sewerage and drainage fall under the supervision of Water and Sanitation Agency that is controlled by the provincial government. In intermediate cities, the Public Health Engineering Department (PHED), a provincial government agency is responsible for such utilities while in some other cities, both municipal committees/ corporations and PHED operate simultaneously.

Insufficient personnel strength in government departments and agencies, to take action with required skill and capabilities, is another major restraint to the orderly and effective development and sustainability of urban settlements.

\section{(d) Enforcement of Planning and Environmental Legislation}

The effective implementation of legislation, if not more, is perhaps as important as law making. Most of the planning and environmental legislation in Pakistan focus on results and penalties, but not on means to achieve results. Substantial legislation related to environmental issues exists in Pakistan, and with time, new legislation has been enacted to cover new developments and environmental protection. Despite these statutory responses however, domestic garbage, industrial and commercial waste along the roadside, and in vacant plots is a usual feature of the landscape. Vehicles, both public and private, pollute the environment with the emission of hazardous smoke and ear-busting horns in the presence of legislation and law enforcing agency. Furthermore, change of land use without prior approval and without consideration of consequences, increase in floor area, street encroachments and violations of building bye-laws are very common irregularities that cause traffic congestion and enhance pollution. Apart from causing inconvenience to the community, these violations set bad examples and negate sustainability of urban areas.

Nevertheless, to a certain extent, the enforcement of environmental legislation is hampered by some inherited deficiencies in the law, as determined by the National Conservation Strategy such as absence of proper definitions, lack of quantified limits and standards, and non-availability of implementation tools etc.

\section{(e) Perception and Information}

Urban environmental policies and actions of governments are highly influenced, inter alia, by the perception of the people and the public officials regarding the nature of environmental degradation in general and in cities in particular. Their perception depends critically on the availability and quality of 
relevant information. In the past it was assumed that the problems of urbanisation could be solved mainly through policies and programmes pursued by the government. In other words, the primary role in establishing housing and settlements policies was assigned to the state, but the time has shown that no matter how resourceful a government may be, it cannot solve the problems without the cooperation of all major actors involved.

\section{TOWARDS EFFECTIVE URBAN ENVIRONMENTAL MANAGEMENT}

\section{(a) Policy and Institutions}

Emerging solutions that gradually coming to surface are mainly based on the partnership of both public and private sector, and participation of informal groups (NGOs and CBOs) and local leadership, community health workers, educationists, economists, entrepreneurs and technical experts. There is a need to enhance the role of the local community in finding and implementing solutions. Through broad-based participation and enabling strategy there is a need to involve all stakeholder, directly affected by urban developments.

The urban management institutions, which form part of the local governments need substantial structural changes. One reason of their current inadequacies is that their mandates and charters are, to a major extent, inadequate to address the magnitude of the problems that they face. Their mandates need to be reviewed with the following as major components:

(1) their planning organisations should be essentially forward looking to the growth imperatives;

(2) they must have the powers and the machinery to take quick decisions and to enforce them;

(3) they should function as catalytic and supporting organisation for generating and enhancing economic activity;

(4) they should be financially self supporting; and

(5) they should have the major authority for local environmental management.

Simultaneously the emphasis needs to be placed on resolving the key urban issues, by setting priorities, formulating appropriate mechanisms for integration of environmental consideration into development process, and enhancing capacities of institution for implementation and enforcement of laws and regulations. 


\section{(b) Setting Priorities}

In view of enormity of problems and shortage of resources it is important to priorities issues. Prioritisation of issues could be based on some universal criteria such as:
(a) health impacts;
(b) productivity losses;
(c) impact on the urban poor;
(d) irreversibility;
(e) unsustainable consumption of resources;
(f) degree of local support/existence of constituencies [Bartone (1991)]; and
(g) level of public awareness.

Whereas the first three criteria are used primarily to determine the immediate curative actions, the last four can be used to set a longer-term agenda for preventive action.

\section{(c) Integrating Environmental Considerations in Urban Development Planning}

It may be noted that successful integration of environmental considerations in metropolitan and urban planning requires three basic operating elements: (1) a simple yet relatively comprehensive information collection and analysis framework to relate key urban development activities to environmental concerns; (2) mechanisms for resolving divergent and sometimes conflicting interests and mandates among metropolitan agencies and jurisdictions to allow coordination between environmental programmes and urban development plans; and (3) a continuous process of policy analysis and refinement that reviews past policy decisions, evaluates policy implementation measures, and prevents a piecemeal approach in policy design and implementation (4) adoption of polluters pay principle by using economic instruments.

\section{(d) Improving Infrastructure Investment Programmes and Adoption of Appropriate Technology}

Appropriate, low-cost technologies designed to make more effective use of existing resources play an important role in maximising the impact of infrastructure investments. For example, considerable progress has been made through the International Water Decade in the development of low-cost appropriate technologies with increased operational reliability. World Bank research has demonstrated that a wide range of household and community systems are available for the collection of 
human wastes, and for the removal of waste water and storm and surface run-off, that are far cheaper than conventional systems [Sinnatamby (1990)]. The solutions should involve low-cost, locally manufactured hardware that can be installed using labour-intensive techniques.

\section{(e) Strengthening Capacity for Implementation and \\ Enforcement}

Implementation and enforcement is crucial to the success of an integrated urban environmental management strategy whether the government adopts a command and control strategy, economic incentives, or a mix of the two. Typically, national authorities should be responsible for establishing environmental policies, regulations, and standards and providing technical and financial assistance to local governments for programme implementation. However, since a majority of our environmental problems are essentially local in character and call for local level action including regulation/control as well as active involvement and cooperation of all stakeholder. Therefore, local authorities capacities needs to be strengthened accordingly to play an effective role in the management of environment. 
Appendix

Appendix Table 1

Output of Privatised Industries

\begin{tabular}{|c|c|c|c|c|c|c|c|c|c|c|c|c|}
\hline \multirow[b]{2}{*}{ Item } & \multirow[b]{2}{*}{ Units } & \multicolumn{6}{|c|}{ Before Privatisation } & \multicolumn{5}{|c|}{ After Privatisation } \\
\hline & & $1985-86$ & 1986-87 & $1987-88$ & 1988-89 & $1989-90$ & 1990-91 & 1991-92 & 1992-93 & 1993-94 & 1994-95 & $1995-96$ \\
\hline Veg. Ghee and Oil & (000)MT & 612 & 609. & 697 & 624 & 683 & 656 & 639 & 725 & 671 & 678 & 693.5 \\
\hline Nitrogenous Fertilisers & (000)MT & 2306.8 & 2497.5 & 2416.1 & 2457.3 & 2541.2 & 2461.4 & 2290.5 & 2701.2 & 3428.5 & 3393.7 & 3724.1 \\
\hline Phosphatic Fertilisers & (000)MT & 427.2 & 2497.5 & 441.5 & 471.5 & 497.2 & 496.1 & 503.8 & 502.3 & 449.5 & 432 & 451.1 \\
\hline Soda Ash & (000)MT & 128.4 & 130.3 & 134.1 & 144.3 & 149.5 & 147.2 & 185.9 & 186.2 & 1873 & 196.1 & 221.1 \\
\hline Caustic Soda & (000)MT & 54.8 & 54.9 & 61.3 & 66.5 & 74 & 78.5 & 82 & 81.4 & 89.1 & 92.7 & 109 \\
\hline Chorine & (000)MT & 7.9 & 7 & 8 & 9 & 7.2 & 6.7 & 6.1 & 5.9 & 5.9 & 7.8 & 9.1 \\
\hline Cement & (000)MT & 5773. & 6508 & 7072 & 7125 & 7488 & 7762 & 8321 & 8558 & 8100 & 8458 & 9446 \\
\hline Switch Gears & Nos & 0 & 0 & 0 & 45420 & 28170 & 24138 & 27612 & 48062 & 53091 & 81640 & 66914 \\
\hline Scooters/Motor Cycles & Nos & 60404 & 41870 & 49453 & 57599 & 71681 & 83146 & 84288 & 88328 & 63958 & 53469 & 85152 \\
\hline Trucks & Nos & 2285 & 1835 & 2238 & 1857 & 1715 & 2.29 & 1629 & 2247 & 1394 & 693 & 1430 \\
\hline Buses & Nos & 616 & 618 & 732 & 777 & 626 & 804 & 1114 & 1177 & 427 & 312 & 382 \\
\hline LCV & Nos & 11566 & 10831 & 10088 & 11899 & 11609 & 11882 & 11461 & 10440 & 5128 & 5154 & 6213 \\
\hline Motor Cars/Jeeps & Nos & 13199 & 15846 & 21663 & 23336 & 27328 & 27971 & 30865 & 28649 & 20330 & 26894 & 33237 \\
\hline Tractors & Nos & 19153 & 18111 & 18584 & 23638 & 19376 & 13753 & 9817 & 17127 & 14656 & 17194 & 16208 \\
\hline
\end{tabular}




\section{REFERENCES}

Asian Development Bank-ADB (1993) Pakistan Urban Sector Profile. Manila: Philippines. Asian Development Bank.

Bartone, Carl (1991) Annotated Outline of a Report on Strategic Option for Managing the Urban Environment. Washington, D. C.: The World Bank. (Draft.)

Leitmann, Josef (1991) Energy-environment Linkages in the Urban Sector. New York: UNDP/World Bank/UNCHS (Discussion Paper Series.)

Pakistan, Government of (1992) The Pakistan National Conservation Strategy. Karachi: Environment and Urban Affairs Division.

Pakistan, Government of (1996) Pakistan National Report to Habital II. Islamabad: Environment and Urban Affairs Division.

Pakistan, Government of (1996a) Environment in Pakistan: Challenges and Achievements. Islamabad: Environment and Urban Affairs Division.

Sinnatamby, Gehan (1990) Low Cost Sanitation. In H. Jorge, C. Sandy and S. David (eds) Poor Die Young. London: Earth Scan Publication.

UNEP (1991) Urban Air Pollution. Nairobi: United Nations Environment Programme. 